\title{
Gramaticalização de construções condicionais em português: trajetórias de mudança do nome caso
}

\section{Grammaticalisation of conditional constructions in Portuguese: courses of change regarding the noun caso}

\author{
Sanderléia Roberta Longhin \\ Universidade Estadual Paulista (Brasil) \\ sanderleia.longhin@unesp.br
}

Enviado: $13 / 11 / 2018$

Aceptado: 26/10/2019

\section{Resumo}

O objetivo deste trabalho é investigar os processos de mudança linguística que deram origem às construçóes condicionais com caso, na história do português. À luz do quadro teórico da gramaticalização (Heine $\& \mathrm{Ku}$ teva 2007; Bybee 2010, 2015), aliado às tendências translinguísticas acerca da emergência de condicionais (Traugott 1985; Kortmann 1997), busco respaldo diacrônico para responder ao quando e ao como dessas mudanças. A análise é fundada em dados extraídos de uma amostra longitudinal, que reúne textos de gêneros diversos, produzidos ao longo dos séculos XIV ao Xx. O eixo central da investigaçáo repousa no exame das propriedades do item nominal fonte que habilitaram a formação de diferentes padrôes funcionais de caso, no âmbito da junçáo condicional. Argumento que o nome caso integra um subconjunto particular de "shell nouns" (Schmid 2000), genéricos e inespecificos, cujas propriedades semântico-cognitivas e textuais permitem explicar sua seleção para expressão condicional nos diferentes padrôes. Os resultados da pesquisa, obtidos na conjugação das abordagens qualitativa e quantitativa, fornecem um conjunto de evidências sobre os contextos condicionadores da mudança, sobre possíveis relações de derivação entre os padrốes de caso e sobre a gradiência na constituição das formas e dos significados.

\section{Palavras-chave}

Gramaticalização; conjunção; português brasileiro; condicionalidade

\section{Sumário}

1. Introdução. 2. Gramaticalização. 2.1. Gramaticalização de marcadores de prótases condicionais. 3. Procedimentos metodológicos. 4. Síntese dos achados na diacronia e as questôes de pesquisa. 5. Processos de mudança envolvendo caso. 5.1. A questáo da fonte nominal. 5.2. A questáo da proposiçáo introduzida por que. 5.3. O estatuto das perífrases preposicionais. 5.4. A relação condicional nas construçôes com caso. 6. Conclusões.

\begin{abstract}
The purpose of this paper is to research the historical change processes leading to conditional constructions with caso in the history of Portuguese. Taking into account the theoretical frame of grammaticalization (Heine \& Kuteva 2007; Bybee 2010, 2015), together with translinguistic trends in the emergence of conditionals (Traugott 1985; Kortmann 1997), the aim is to find diachronic support to provide answers to the when and how for these changes. This analysis is based on data extracted from a longitudinal sample comprising texts from various genres, written between the $14^{\text {th }}$ and $20^{\text {th }}$ century. The research centres on the analysis of properties of the source nominal item which have enabled the development of different functional patterns of caso, in the domain of conditional junction. The argument presented herein is that the noun caso belongs to a particular subset of generic and unspecific "shell nouns" (Schmid 2000) whose semantic-cognitive and textual properties explain its choice for conditional expression in different patterns. The research results obtained by joining qualitative and quantitative approaches provide a set of evidence about change-conditioning contexts, about likely derivation relationships among the patterns of caso and about the gradience in the constitution of forms and meanings.
\end{abstract}

\section{Keywords}

Grammaticalization; conjunction; Brazilian Portuguese; conditionality

\section{Contents}

1. Introduction. 2. Grammaticalization. 2.1. Grammaticalization of conditional protasis markers. 3 . Methodological procedures. 4. Summary of the findings in diachrony and research issues. 5. Change processes involving caso. 5.1. The issue of the nominal source. 5.2. The issue of the proposition introduced by que. 5.3. The status of prepositional periphrases. 5.4. The conditional relationship in constructions with caso. 6. Conclusions. 


\section{Introdução}

To português brasileiro contemporâneo, convivem construçóes que comportam 1 em sua estrutura o nome caso e que são empregadas para expressão de condicionalidade, conforme os dados de (1) a (4), a seguir, extraídos do corpus desta pesquisa. Trata-se de construçóes complexas binárias em que o elemento de junção, ora preposicional ((1) e (2)), ora conjuncional ((3) e (4)), atua como marcador de prótase condicional:

(1) [...] Mas este peixe só deve ser admittido em caso de necessidade. (20CDC, 52)

(2) Os filhos menores são postos em tutela, em caso de os pais decaírem do poder familiar. (20CCB, 363)

(3) Caso os parlamentares o rejeitem, cessa de jure a exceção. (20RFD, 155)

(4) As determinaçóes do parágrafo precedente se aplicarão com as necessárias modificaçóes, nos casos em que haja defeito no assentamento ou no suporte de bambus ou de madeira. (20RFD, 120)

Estudos acerca de caso (Ali 1931; Leão 1961; Barreto 1999; Gerards \& Kabatek 2018) sugerem que a constituiçấo da conjunção caso, conforme (3), seja resultado da reanálise de construçóes frasais com núcleo nominal, tais como sendo o caso que, nos casos em que, caso que, que experimentaram, ao longo do tempo, contínua descategorizaçáo e perda de material morfológico:

A conjunção caso (em caso venha, caso chova) procede da reduçáo de caso que, a qual maneira de dizer é por sua vez forma reduzida de sendo caso que. (Ali 1931: 261).

[...] no caso (em) que é fórmula pesada e deselegante. Encurta-se em caso, conjunção que dá mais agilidade à frase. (Leão 1961: 71)

[...] caso perdeu o seu conteúdo semântico de origem e assimilou o da conjunção que, condicional, formando com ela um único item, para expressar a relação de condição. Posteriormente, [...] caso, já imbuído do valor semântico condicional, passa a ser empregado isoladamente. (Barreto 1999: 359)

[...] we gave evidence of how em caso que was further reduced to caso que, which, crucially, seemed to be a better choice in contexts of communicative immediacy than $\mathrm{em}$ caso que. [...] Most likely, as we briefly suggested, this has to do with the fact that the complementizer que came to be omitted on a regular basis, bringing about the genesis of a highly remarkable use of caso (Gerards \& Kabatek 2018)

Palavra de origem latina, o nome caso é derivado do verbo cadere, equivalente a cair, nos sentidos físico e moral. A forma nominalizada casus se referia tanto a aquele de cai, acepção mais concreta, como às noçôes estendidas de ocasião, acaso, casualidade e oportunidade, mais abstratas (Ernout \& Meillet 1951: 145). Em várias línguas, 
caso e seus correspondentes seguiram trajetórias similares de mudança em direção a mecanismos de junção condicional, como evidenciam, por exemplo, Trudgill (1995), sobre usos de in case e case, em dialetos do leste da Inglaterra; Visconti (2000), sobre nel caso chelin cui, in caso e casomai, no italiano; Montolío (2000), Barra Jover (2002) e Granvik (2015, 2018), sobre (en) (el) caso (de) que, no espanhol; e Alexe (2013), sobre în cazul în care e în caz ca, no Romeno. Em várias dessas instâncias, a origem nominal permanece relativamente transparente.

O objetivo deste trabalho é investigar determinados aspectos dos processos de mudança linguística que deram origem às construçóes condicionais com caso, na história do português. À luz do quadro teórico da gramaticalização (Heine \& Kuteva 2007), aliado às tendências translinguísticas acerca da emergência de condicionais (Traugott 1985; Kortmann 1997), busco respaldo diacrônico para responder ao quando e ao como dessas mudanças. Nessa perspectiva, este trabalho corrobora alguns dos resultados da pesquisa recente de Gerards e Kabatek (2018). Com base no Corpus do Português, os autores investigaram os diferentes processos evolutivos de caso - como construçáo complexa que veicula condição (em/no caso de, em/no caso que), como conjunção condicional simples (caso) e como modalizador epistêmico (acaso) -, com o propósito maior de explorar a correlação entre os paradigmas da gramaticalização, das tradiçôes discursivas e do contínuo distância e proximidade comunicativa. Gerards e Kabatek (2018) demonstraram o peso de tradiçôes discursivas particulares, de ambos os eixos da proximidade e da distância comunicativa, enquanto locus das inovações e mudanças que afetaram caso.

No presente trabalho, o eixo central de investigação repousa no exame das propriedades do item nominal fonte que habilitaram a formaçáo de diferentes padróes funcionais de caso. Argumento que o nome caso integra um subconjunto particular de nomes shell (cf. Schmid 2000) ${ }^{1}$, genéricos e inespecificos, que muito se aproximam de verbos em razão da necessidade de complementação. Como se verá, propriedades semântico-cognitivas e textuais de caso explicam sua seleção para expressão condicional nos diferentes esquemas léxico-gramaticais, fornecem evidências acerca dos contextos condicionadores e permitem apreender aspectos da gradiência na constituição das formas e dos significados.

Organizo o texto em cinco seçôes, além desta introdutória. Na Seção 2, exponho as bases da teoria que fornece os subsídios para descriçáo de processos de mudança e abordo tendências translinguísticas acerca de fontes de marcadores condicionais. Na Seção 3, explicito os critérios utilizados para a constituição do corpus diacrônico e as decisóes metodológicas para descrição e análise dos dados. Na Seção 4, apresento uma síntese dos achados na diacronia, que permitirá delinear questôes de pesquisa, a serem respondidas na Seção 5, onde ofereço uma explicação para a

1. Opto por manter a terminologia do inglês shell nouns, em lugar de possíveis denominações em português (encapsulador, contêiner, concha, etc.). Ainda que a expressão encapsulador seja relativamente consensual na literatura, ela capta apenas parte do funcionamento desses nomes (Schmid 2000). 
emergência das construções condicionais com caso. Fecho o texto com as conclusões, na Seção 6.

\section{Gramaticalização}

As construções com caso são analisadas no quadro teórico-metodológico da mudança por gramaticalização, entendida como processo gradual em que construções menos gramaticais, usadas em contextos pragmáticos e morfossintáticos altamente específicos, se tornam mais gramaticais, em consequência de um conjunto de alteraçóes que afeta a morfossintaxe, o significado e, em alguns casos, a substância fonética (Heine \& Kuteva 2007; Bybee 2010, 2015). Como o processo envolve interaçáo entre os vários componentes linguísticos, a construção ${ }^{2}$ é a unidade de análise por excelência para descrição de instâncias do processo (Heine \& Kuteva 2007: 32).

Desde o trabalho seminal de Meillet (1912), a gramaticalização vem sendo reconhecida como o principal mecanismo que possibilita a criação e o desenvolvimento de construçôes gramaticais nas línguas. Nas últimas décadas, a profusão de estudos em gramaticalização tem contribuído, de maneira crucial, para a compreensão da natureza da gramática como sistema adaptativo e complexo (Bybee 2010), no qual as relações entre formas e funções são indissociáveis e instáveis. A indissociabilidade decorre da não autonomia da língua frente às forças cognitivas e socioculturais, enquanto a instabilidade decorre da contínua e gradual reorganização da gramática, flagrada na fluidez das categorias e na coexistência entre padrões de uso estáveis e emergentes.

Dentre os fatores e mecanismos inerentes à gramaticalização, neste trabalho, estarão em pauta sobretudo aspectos relacionados à direcionalidade da mudança, ao potencial para formaçáo de chunks e às propriedades gradientes de analisabilidade e composicionalidade. A direcionalidade da gramaticalizaçáo é reconhecidamente uma propriedade robusta, inscrita na própria definição de gramaticalização, que prevê um ganho contínuo de informaçáo mais gramatical, mais abstrata e mais subjetiva. Em especial, no domínio das alteraçóes de significado, o fenômeno da subjetivização, entendido como processo semântico-pragmático em que os significados se tornam cada vez mais vinculados à atitude expressiva/crença do usuário da língua, tem sido um lugar privilegiado para exploração de uma face da direcionalidade da mudança que é fortemente impulsionada por fatores sócio-cognitivos (Traugott 1995). Nesses termos, a direcionalidade é uma evidência de que as mudanças não se dão aleatoriamente.

A noção de chunk, tal como explorada em Bybee (2010), é relevante para a compreensão das formaçóes frasais envolvendo caso (sendo caso que, no caso em que, em

2. Entendo construção como produto da associação de um valor semântico com propriedades distribucionais, nos níveis da palavra, do sintagma e da oração. Ainda que essa posição mostre estreitos paralelos com as vertentes de gramáticas construcionais, não tenho aqui compromisso com esses paradigmas teóricos. 
caso que, em caso de, etc.). Entende-se por chunk uma sequência de palavras que, em função de determinaçóes contextuais, passa a ser processada e enunciada conjuntamente, como um bloco. A exposição dessas sequências à repetição contínua favorece a perda de transparência em ambos os níveis morfossintático e semântico, e confere aos chunks graus crescentes de convencionalização. Conforme Bybee (2010), chunks são parcialmente esquemáticos, ou seja, são construçôes em que interagem o fixo (porção estável) e o lacunar (posição variável passível de preenchimento).

Associadas à noção de chunk estão as medidas de composicionalidade e analisabilidade (Bybee 2010) que, embora distintas, são estreitamente relacionadas. A composicionalidade é semântica, refere-se ao grau de previsibilidade do significado da construção a partir do significado de suas partes. Por outro lado, a analisabilidade é morfossintática, refere-se ao grau de reconhecimento das partes componentes (morfemas, palavras) e à contribuição de cada uma para a constituição do significado da construção. Com o avanço da mudança em diferentes estágios, impulsionado pela frequência de uso, tem-se um jogo de manutenção e de perda gradual de traços de analisabilidade e de composicionalidade, tão fundamentais para a composição da nova unidade (Kortmann 1997; Bybee 2010, 2015).

\subsection{Gramaticalização de marcadores de prótases condicionais}

Segundo Kortmann (1997: 89), nos processos de gramaticalização que levam à formação de conectores adverbiais, o que motiva a seleção de uma certa fonte lexical é principalmente o arranjo particular dos significados envolvidos com o item e com as construçôes de que ele participa. Sobre o reconhecimento das fontes e das rotas potenciais à constituição de marcadores de prótase condicional nas línguas, Traugott (1985) está entre as maiores referências. Segundo ela, a tendência geral é a de que as fontes de condicionais sejam recrutadas entre as palavras lexicais ou gramaticais mais abstratas, já que as relações condicionais envolvem abstração e subjetivização, vinculadas que estão a pressuposiçôes sobre mundos possíveis e hipotéticos.

A partir da sistematização de um conjunto de trabalhos sobre línguas geneticamente não relacionadas, Traugott (1985) reconhece cinco domínios léxico-gramaticais que atuam mais frequentemente como fontes para ampliaçáo dos marcadores condicionais e que, dada a perspectiva translinguística, assumem o estatuto de fatores universais no desenvolvimento histórico de condicionais. Sáo eles: modais epistêmicos e optativos, cópulas existenciais, construçóes interrogativas, marcadores de tópico e expressôes temporais. Mais instigante, porém, é a correlação que a autora estabelece entre as fontes léxico-gramaticais e as funções semânticas das construçóes condicionais, o que lhe autoriza explorar as motivaçóes da mudança semântica e, ao final, elaborar um mapa semântico-cognitivo acerca dos principais caminhos de desenvolvimento. 
Com o propósito de legitimar correlaçóes entre fonte e alvo, Traugott argumenta que a seleção de modais epistêmicos e optativos é plausível à luz da função que os condicionais têm de abertura de possibilidades, sejam elas reais, potenciais ou irreais; que a seleção das cópulas se relaciona estreitamente à existência de mundos possíveis; que a seleção de perguntas polares, em contextos de interação, remete a mundos alternativos e hipotéticos; que marcadores de tópico, assim como prótases condicionais, veiculam informação pressuposta e mobilizam frames; e que expressões temporais, especialmente as vinculadas à duraçáo e à contingência, estão relacionadas à condicionalidade, uma vez que a repetiçáo regular e/ou necessária em vários períodos de tempo habilita a inferência de uma implicação.

\section{Procedimentos metodológicos}

Em consonância com o objetivo maior de conduzir uma investigação em tempo real acerca das transformaçôes sintático-semânticas das construçôes com caso, a via metodológica longitudinal é a que norteia a pesquisa e o material de investigação consiste em textos escritos produzidos em diferentes momentos da história do português, nas variedades europeia e brasileira (PE e PB, daqui em diante). Ciente da importância de utilizar um corpus representativo que possibilite identificar estágios sucessivos dos processos diacrônicos em pauta e ciente também da complexidade que envolve a seleção da documentação histórica, para seleção da amostra e constituição do corpus, baseio-me nos seguintes critérios: temporal, textual qualitativo e textual quantitativo.

Quanto ao critério temporal, equiparando metodologicamente sincronias a séculos, selecionei textos dos séculos XIV a Xx, totalizando sete sincronias representativas de diferentes estados do português. A consideração de períodos pretéritos da língua levou à seleção de textos unicamente do PE, em específico para os séculos XIV a XVII. No material do século XVIII, há mescla de textos produzidos em Portugal e no Brasil, com prevalência de textos do PE. A partir do século xIX, há prevalência de textos do $\mathrm{PB}$, com apenas um texto do PE para cada estado de língua ${ }^{3}$.

Quanto ao textual qualitativo, priorizei para cada recorte temporal uma seleção comparável de tipos textuais argumentativo, prescritivo e narrativo, com a expectativa de que a diversidade textual favorecesse dados das várias construçóes envolvendo caso e de que a simetria de tipologias entre as sincronias reduzisse o risco de resultados enviesados. Os textos foram extraídos de quatro plataformas: Tycho Brahe Parsed

3. Do material do século xvinI, foram selecionados cinco textos do PE (18HPL, 18SCR, 18RVH, 18SVP, 18COB), dois textos do PB (18CSA, 18OFB) além da coletânea Caminhando Mato Dentro (18CMD), que reúne textos de ambas as variedades. Do material dos séculos XIX e Xx, os textos referidos como 19NHG e 20CDC provêm do PE. As siglas estão especificadas no Anexo. 
Corpus of Historical Portuguese, Banco Informatizado de textos do Projeto de História do Português Brasileiro; Projeto de História do Português Paulista; e Acervo digital da Biblioteca Brasiliana Guita e José Mindlin ${ }^{4}$. A relação completa dos textos e as respectivas siglas de referência são apresentadas ao final, no Anexo. Quanto ao critério textual quantitativo, visando a garantir uma simetria na quantidade de material, estabeleci de sete a nove textos para cada sincronia e promovi um recorte de cerca de 300.000 palavras por sincronia ${ }^{5}$. A Tabela 1 , a seguir, exibe o número de palavras e a frequência token de caso, nos estados de língua considerados, o que perfaz o total de 815 dados que fundamentam a análise. ${ }^{6}$

\begin{tabular}{lllllllll}
\cline { 2 - 8 } & \multicolumn{1}{c}{ XIV } & \multicolumn{1}{c}{ XV } & \multicolumn{1}{c}{ XVI } & \multicolumn{1}{c}{ XVII } & \multicolumn{1}{c}{ XVIII } & \multicolumn{1}{c}{ XIX } & \multicolumn{1}{c}{ xx } & \multicolumn{1}{c}{ TotAL } \\
\hline N.o de palavras & 325.595 & 308.154 & 327.214 & 306.956 & 303.424 & 304.233 & 307.293 & 2.182 .869 \\
Dados de caso & 18 & 101 & 130 & 182 & 90 & 137 & 157 & 815 \\
\hline
\end{tabular}

Tabela 1. Frequência token de caso por estado de língua

A metodologia de investigação conjuga as abordagens quantitativa e qualitativa. Para o mapeamento das construçóes no tempo, contemplo, além do padrão nominal, os três padróes léxico-gramaticais de caso, conforme exemplificados a seguir, no Quadro 1. A frequência dos padróes será tomada, à maneira de Bybee (2015), como um indicativo de mudança, já que o aumento da frequência pode ser índice de construçóes mais produtivas, mais acessíveis, mais generalizadas em significado. Nos casos em que a frequência dos dados não fornece o respaldo necessário, a abordagem qualitativa das ocorrências é que se sobrepóe.

$\mathrm{Na}$ descrição, focalizo a constituição das perífrases conjuncionais e preposicionais que, entendidas como construçóes, decorrem da reanálise gradual de elementos de diferentes classes gramaticais. Focalizo também a composição complexa que as perífrases ajudam a constituir, cuja interpretação global requer a mobilização de elementos formais, dentre os quais a natureza do juntor, a ordem das oraçóes e a morfologia

4. Os dados estão disponíveis em: www.tycho.iel.unicamp.br/-tycho; www.prohpor.org/\#!bit-prohpor; http://phpp.fflch.usp.br/corpus e www.bbm.usp.br.

5. Os textos da amostra encontram-se em formato $d o c$ ou $p d f$, o que permitiu uma busca automática pelos dados de caso - cazo. Todas as ocorrências foram extraídas considerando-se o contexto maior em que se inserem, e posteriormente foram tabuladas e submetidas a programa computacional, para apuração das frequências e correlação entre os fatores. Agradeço à aluna Raissa Tavares Niza pelo grande trabalho com o recorte dos textos, levantamento e tabulação dos dados, tarefa que realizou, sob minha orientação, como parte das atividades de seu projeto de iniciação científica, intitulado Gramaticalização de conjunçôes condicionais (Fapesp, 2017/00654-1).

6. As ocorrências incluem os padrôes nominais, conjuncionais e preposicionais de caso. Foram excluídos desse montante os dados de fazer caso (49 ocorrências), em todo caso (21 ocorrências) e acaso (76 ocorrências), que merecem um estudo à parte e que, portanto, não serão contemplados neste trabalho. 
verbal, juntamente com mecanismos inferenciais que legitimam relaçóes diversas que podem se estabelecer entre prótases e apódoses (Sweetser 1990; Dancygier 2003).

\begin{tabular}{|c|c|}
\hline CONSTRUÇÃO COM caso & EXEMPLARES \\
\hline em(o)(s) caso(s) (em) que & $\begin{array}{l}\text { [...] E nos casos em que isso affectasse a matéria medica, não omitti- } \\
\text { ríamos as devidas cautelas, e avisos em quaesquer casos indecifráveis. } \\
(19 \text { SMM, 19) }\end{array}$ \\
\hline$(e m)(o)(s) \operatorname{caso}(s) d e$ & $\begin{array}{l}\text { Relevem portanto, Senhores Redactores, que por meio de sua folha, cha- } \\
\text { memos a attençáo da camara municipal, para o que levamos dito, afim } \\
\text { de que activem os Senhores fiscaes ou demittão-os no caso de reincidirem } \\
\text { no seu proverbial deleixo. (19CCB, 27) }\end{array}$ \\
\hline caso & $\begin{array}{l}\text { O comprador só tem que me pagar separadamente os animaes e criação } \\
\text { que me pertencem, caso lhe convenha o preço. (19CWL, 72) }\end{array}$ \\
\hline
\end{tabular}

Quadro 1. Padróes léxico-gramaticais de caso

Como a apuração dos graus de composicionalidade e de analisabilidade estará em pauta, para operacionalização das análises, seguindo Kortmann (1997), elejo traços caracterizadores de conjunçóes e de perífrases conjuncionais prototípicas e os adapto ainda para as preposiçóes complexas. Para Kortmann (1997: 71), os conectores prototípicos, correspondentes a uma única palavra, devem preencher o conjunto de condições a seguir, que envolve tanto aspectos morfossintáticos do próprio item, como da construção como um todo: i) são constituídos por uma forma livre não flexionada; ii) podem introduzir uma oração subordinada finita, i.é, uma construção estruturada em sujeito-predicado; iii) não desempenham função sintática no interior da oraçáo em que ocupam; iv) assumem posição rígida na margem da oração; v) não pertencem a variedades linguísticas marcadas (dialeto regional, uso arcaico); e, vi) em línguas em que a posição da oração adverbial é variável, a oração modificadora tende a preceder a oração núcleo.

Nos casos de perífrases conjuncionais, sobretudo as que envolvem nome seguido de complementizador ou relativizador, Kortmann (1997: 73) argumenta que pelo menos uma das três condiçóes a seguir deve ser preenchida: i) os elementos da perífrase devem exibir um grau mínimo de fusão; ii) devem ter perdido pelo menos algumas das propriedades do sintagma original; e, iii) devem ter pelo menos um significado que não seja totalmente recuperável a partir do significado das partes (não-composicionalidade). Esses critérios são refinados na próxima seção, em que, a partir do mapa diacrônico das construçóes com caso, especifico questôes de pesquisa e explicito as decisões metodológicas correspondentes. 


\section{Síntese dos achados na diacronia e as questóes de pesquisa}

A Tabela 2 ilustra as frequências absoluta e percentual dos vários padróes funcionais de caso, em perspectiva longitudinal. Ela permite vislumbrar tendências, das quais decorrem as questóes de pesquisa que formulo adiante. A espessura dos traços na tabela delimita os quatro padróes léxico-gramaticais de caso: nome, perífrase conjuncional, perífrase preposicional e conjunção.

\begin{tabular}{|c|c|c|c|c|c|c|c|}
\hline & XIV & $\mathrm{xV}$ & XVI & XVII & XVIII & XIX & $\mathrm{xX}$ \\
\hline \multirow[t]{2}{*}{ caso (nome) } & $17 / 18$ & $99 / 101$ & $111 / 130$ & $168 / 182$ & $61 / 89$ & $119 / 137$ & $113 / 157$ \\
\hline & $95 \%$ & $98 \%$ & $86 \%$ & $92 \%$ & $68 \%$ & $87 \%$ & $72 \%$ \\
\hline \multirow[t]{2}{*}{ em caso que } & $1 / 18$ & $1 / 101$ & $8 / 130$ & $6 / 182$ & $4 / 89$ & 0 & 0 \\
\hline & $5 \%$ & $1 \%$ & $6 \%$ & $3 \%$ & $4 \%$ & & \\
\hline \multirow[t]{2}{*}{ sendo caso que } & 0 & $1 / 101$ & $8 / 130$ & 0 & $5 / 89$ & $1 / 137$ & 0 \\
\hline & & $1 \%$ & $6 \%$ & & $6 \%$ & $0,5 \%$ & \\
\hline \multirow[t]{2}{*}{$n o(s)$ caso $(s)(\mathrm{em})$ que } & 0 & 0 & $2 / 130$ & $3 / 182$ & $6 / 89$ & $7 / 137$ & $4 / 157$ \\
\hline & & & $1,5 \%$ & $1,5 \%$ & $7 \%$ & $5 \%$ & $3 \%$ \\
\hline \multirow[t]{2}{*}{ caso que } & 0 & 0 & $1 / 130$ & 0 & 0 & 0 & 0 \\
\hline & & & $0,5 \%$ & & & & \\
\hline \multirow[t]{2}{*}{ em caso de } & 0 & 0 & 0 & $3 / 182$ & $2 / 89$ & $1 / 137$ & $14 / 157$ \\
\hline & & & & $1,5 \%$ & $2 \%$ & $0,5 \%$ & $9 \%$ \\
\hline \multirow[t]{2}{*}{$n o(s) \operatorname{caso}(s) d e$} & 0 & 0 & 0 & $2 / 182$ & $10 / 89$ & $4 / 137$ & $18 / 157$ \\
\hline & & & & $1 \%$ & $11 \%$ & $3 \%$ & $11 \%$ \\
\hline \multirow[t]{2}{*}{ caso (conjunção) } & 0 & 0 & 0 & 0 & $2 / 89$ & $5 / 137$ & $8 / 157$ \\
\hline & & & & & $2 \%$ & $4 \%$ & $5 \%$ \\
\hline
\end{tabular}

Tabela 2. Frequência dos padróes de caso em perspectiva longitudinal

1) A frequência da forma fonte, o nome caso, é sempre muito maior do que as formas derivadas, em todos os estados de língua. Bybee (2010) reúne evidências de que a frequência das formas complexas derivadas é maior do que a da fonte quando as derivadas são menos composicionais. Nesses termos, essas frequências podem estar apontando para a manutenção da analisabilidade e transparência das formas derivadas, o que será examinado adiante. Nos dados, caso é nome que expressa uma circunstância, atualizada em diferentes contextos de uso, como em (5), em que caso se refere ao cisma da igreja. Aparece frequentemente em sintagmas preposicionais, podendo ser acompanhado de modificadores diversos, inclusive oraçóes relativas, conforme (6).

(5) Dizee a meu filho, o iffante dô Johã, que açerca da çisma que he na igreja, lhe rogo que aja sobre elo boo consselho, ca he hũu caso muy periigoso e muy duvydoso. (14CDA) 
(6) E diga aos Juizes, que quando os feitos forem graves, que ainda que alguma das partes nom appelle, que elles appellem pola Justiça pera a Nossa Corte naquelles feitos, e casos, em que lhes per nós he mandado, que appellem pola Justiça. (15LMP)

Conforme se observa na Tabela 2, as frequências das construçóes em estágio de mudança rumo a mecanismos de junção são baixas, o que quebra expectativas diante da impossibilidade de generalizaçôes. Contudo, como se verá nas próximas seções, do ponto de vista qualitativo, os dados trazem indícios preciosos acerca da reanálise sintático-semântica das construçôes. Já as frequências da fonte nominal são bastante altas e viabilizam o propósito de focalizar as características do item fonte em seus contextos de uso.

2) As primeiras instâncias de perífrases conjuncionais - em caso que e sendo caso que - surgem nos dados do português arcaico, reforçando em grande parte os resultados de Gerards e Kabatek (2018). Conforme as ocorrências em (7) e (8), nas oraçôes complexas de que caso participa, há expressão de condicionalidade. Em ambas, caso junta-se a uma proposição introduzida por que, que se realiza no imperfeito do subjuntivo. Mas, na primeira instância, caso está em sintagma preposicional e, na segunda, em oração reduzida de gerúndio. A chave do enigma diacrônico está, em grande parte, na compreensão da habilidade de caso adjungir-se a que.

(7) Outros dizẽ que ẽ tal caso como este he necessario despẽsaçố do papa. Porque o teu preposyto foi de o matar. Mas ẽ caso que o teu preposyto nó fosse de matar nẽhuũ e porẽ matasteo ẽ tal caso nô he necesaria a despẽsaçó do papa. (15TC)

(8) De tudo o que lhe assi deu, fez Condado chamado o Condado de Portugal, com tal condição, que o Conde Dom Anrique o servisse, e fosse às suas Cortes, e chamados, e sendo caso que fosse doente, ou tivesse legítimo impedimento a não poder lá ir, lhe mandasse um dos mais principais de sua terra a ser serviço com trezentos de cavalo. (14CDA)

A constituição de perífrases conjuncionais em que na história do português e demais línguas românicas é fruto de uma tendência, já incipiente no latim tardio, que consistia na combinação de palavras de categorias diversas, sobretudo advérbios e preposições, com quod (Herman 1963; Maurer 1959; Câmara 1979; Barra Jover, 2002). Como fenômeno panromânico, o esquema $x+q u o d$ ganhou poder analógico, tornando-se um molde para formação de novas conjunções. Mas o potencial analógico é relativo, como ressalva Barra Jover (2002: 58), visto que estudos empíricos evidenciam que nem todo advérbio ou preposição aceita que; os que aceitam o fazem 
com maior ou menor resistência; e as criaçóes novas têm frequência bastante variável nas diferentes línguas.

Barra Jover (2002) focaliza as condições sintáticas que predispóem as formações $x+q u e$ do espanhol, em particular as propriedades lexicais de $x$ que autorizam a regência da proposiçáo iniciada por que. A hipótese de Barra Jover (2002: 357) para os casos em que $x$ é saturada por um nome (por exemplo, caso) é: um dado nome, se pode designar um conteúdo proposicional e se o faz em sintagmas que recuperam conteúdo proposicional anaforicamente, entáo esse nome poderá aparecer em um sintagma preposicional que se junta a uma proposiçáo iniciada por que. Em outras palavras, para o autor, a foricidade é a propriedade lexical mais decisiva para habilitaçáo de $x$ à regência de que, o que reforça a tese de que a combinação $x+q u e$ não é, de fato, mecânica. Essa hipótese reforça ainda mais a estreita relação entre foricidade e junção: a foricidade é um dos pilares da perspectiva multidimensional de junção proposta em Raible (2001); também é ela que fundamenta a conexão adverbial nos termos de Blühdorn (2008); e, pelo viés da mudança, é a foricidade que torna tão ativa a derivação de conjunçóes a partir de advérbios (Traugott 1985; Mithun 1988).

Considerando que os primeiros usos em que caso integra prótases condicionais são instâncias de articulação com uma proposição introduzida por que, busco explicitar as condiçóes sintático-semânticas que permitiram a combinação. Para tanto, aproximando-me de Barra Jover, sigo duas vias de investigação, uma em direção a uma descrição mais fina das características da fonte nominal (Seção 5.1) e outra, em direção às propriedades da proposição iniciada por que (Seção 5.2).

3) As perífrases preposicionais são mais tardias7. Nos dados, aparecem somente a partir do século XVII e suas frequências são mais consideráveis no português contemporâneo. Coexistem duas estruturas, uma é no(s) caso(s) de, que mostra traços morfossintáticos inerentes ao nome, tais como presença de determinante artigo e flexão de número; e a outra é em caso de, sem marcas nominais. Conforme os dados, inicialmente, ambos os padróes estruturais são complementados por nomes. Parece haver, contudo, uma diferença fundamental que é de ordem semântica: nos dados do século XVII, em caso de, mas não no(s) caso(s) de, expressa condição, conforme evidencia a comparação entre (9) e (10):

(9) [...] Aquelle moço naó era cativo; porque os pays só podem vender seus filhos em caso de muito grande necessidade. (17CPV)

(10) [...] Também se lhes disse, que esta supposiçaó era contra a mesma Ley, na qual Sua Magestade dispoem o que se ha de fazer no caso da guera justa. (17CPV)

7. Na história do espanhol, conforme Barra Jover (2002: 386), as formas preposicionais envolvendo caso também são posteriores às conjuncionais com que. 
Nos demais estados de língua, o padrão no(s) caso(s) de passa a veicular condição em alguns contextos. A partir do século XviII, ambos os padróes admitem a complementação por nomes e por oraçóes não finitas, de que (11) é exemplar ${ }^{8}$ :

(11) Só pertence aos Iuizes o arbitrio no exame das provas, para que cada hum as possa julgar, conforme entender, que verificaó, ou naô verificaó bastantemente os delitos; e para que no cazo de os naó acharem provados o que baste, possaó absolver os Reos, que delles estiverem arquidos. (18CMD)

Para construçôes de (9) a (11), e correspondentes em outras línguas, falta consenso na literatura sobre o próprio estatuto enquanto preposiçóes complexas (Alexe 2013; Bybee 2010). Os posicionamentos variam desde o reconhecimento de uma categoria difusa, com gradiência de forma e de significado, até a negação da existência de preposiçóes complexas. Do ponto de vista da mudança, cabe examinar, para cada instância, o grau de analisabilidade e de composicionalidade. Se caso admite determinantes, modificadores e é passível de flexão em número, então seu grau de analisabilidade é alto, o que indicia fraca gramaticalização. Considerando a coexistência de em caso de e no(s) caso(s) de no português contemporâneo, com suas diferenças formais e semânticas, é possível supor que elas estejam exibindo, até hoje, graus diferentes de analisabilidade e de composicionalidade. Nesse cenário, a questão que se coloca é a de apurar diacronicamente, para essas construçóes, a frequência dos diferentes graus, com a finalidade de avaliar maiores ou menores índices de gramaticalização (Seção 5.3).

4) A emergência da conjunção caso é posterior às estruturas perifrásticas. Nos dados, a primeira ocorrência verificada, conforme (12), data do século XviII, o que mais uma vez ratifica os resultados de Gerards e Kabatek (2018). Trata-se de uma condicional potencial, em que a prótase expressa uma possibilidade compatível com circunstâncias reais específicas (possibilidade de tormenta de vento), que justifica a afirmação prévia expressa na apódose (rodear uma ilha para servir de amparo). Nessa ocorrência, a posposição da condicional é um fator importante para a interpretação global: a oração introduzida pela conjunção caso acrescenta um fato contingente que, no contexto, é reanalisado como razão ou justificativa. Razóes e justificativas no âmbito textual, em geral, ocupam segunda posição. Assim, a articulação dessas oraçóes por meio de caso representa uma aproximaçáo entre contingência e justificativa.

8. No PB contemporâneo, em gêneros formais, ainda que em frequência muito reduzida, as construçôes preposicionais com caso podem reger oração desenvolvida, como em: têem-se dois bules de prata, um para o chá preto, que é o que se toma vulgarmente, o outro para o chá verde, no caso de que alguém peça, única ocorrência verificada no corpus. 
(12) [...] Navegamos thé as quatro hóras, ehũ quarto datarde, que hindo procurar terra achamos hũ grande baixio deareya encalhando as Embaraçoens [...]; sahimos deste baixio, e fomos rodeando huã Ilha para nos servir de amparo cazo houvésse tormenta de vento. (18CMD)

Visando a investigar relaçóes de derivação entre os diferentes padrôes de caso, possíveis evidências de que a conjunção caso pode ser produto da redução de formas conjuncionais perifrásticas poderiam ser buscadas no exame do tipo de relaçáo condicional de que as construçôes com caso participam. Segundo tendências filogenéticas, se uma mudança semântica resulta em uma condicional, é mais provável que a condicionalidade seja expressa no domínio sócio-físico e que, só mais tarde, desenvolva usos epistêmicos e conversacionais (Sweetser 1990; Kortmann 1997: 168). Essa tendência é alimentada pelo elo metafórico que existe entre os domínios cognitivos e que pode levar à extensão de significados do domínio referencial para os domínios mental e social, gerando ambiguidade pragmática. Nesses termos, a questão que se coloca é a de verificar, à luz dos domínios cognitivos, se há alguma continuidade entre as relaçóes condicionais expressas nas construçôes perifrásticas com que e aquelas nas construções com a conjunção caso, que poderia servir como argumento em favor da derivação (Seção 5.4).

\section{Processos de mudança envolvendo caso}

\subsection{A questão da fonte nominal}

Um entendimento mais circunstanciado sobre a natureza nominal de caso é fundamental para a compreensão de suas várias trajetórias de mudança. Neste trabalho, entendo que caso é parte de uma classe heterogênea de nomes abstratos (que abriga fato, problema, posição, razão, coisa, questão, situação, objetivo, entre outros), que pode funcionar, em determinados usos, como shell nouns, conceito extensamente refinado em Schmid $(2000,2007)^{9}$. A noção de shell nouns se fundamenta na propriedade que esses nomes têm de englobar porçóes variáveis de informaçóes, muitas vezes maiores que uma oração.

9. Segundo Schmid (2000: 4), há dezenas de nomes dessa espécie, distribuídos em um contínuo de maior e menor tipicidade, passíveis de organização em pelo menos seis classes: factual (fato, coisa, problema, razão), linguístico (mensagem, proposta, questão, ordem), mental (ideia, noção, crença, objetivo, decisão), modal (possibilidade, necessidade, habilidade), evento (ato, reação, tentativa), circunstancial (lugar, situação, tempo, modo, caso). $\mathrm{Na}$ classificação do autor, case do inglês (port. caso) figura entre os shell nouns circunstanciais, aqueles que se referem a situações, tempos, localizaçóes, modo de fazer coisas e condiçóes para fazer coisas. 
Os shell nouns têm uma estrutura semântica característica, que compreende a combinação de dois traços: abstração e inespecificidade. A abstração decorre do fato de que eles expressam entidades de nível mais alto, entidades de segunda ordem, relativas a eventos vinculados ao mundo físico (processos, estados, atividades); e entidades de terceira ordem, relativas a proposiçôes, ideias e conceitos, vinculadas ao mundo mental. A inespecificidade, por sua vez, decorre da propriedade valencial do shell noun, que estabelece uma 'lacuna' a ser preenchida para uma comunicação bem-sucedida.

Segundo Schmid (2000), o que garante que os shell nouns sejam reconhecidos como uma classe funcional é a confluência entre as funçóes semântico-cognitivas e textuais, comum a todos eles. A função semântica se refere ao potencial de caracterização inerente aos nomes, que equivale ao tipo de experiência expresso, nas tantas situaçóes de uso. Nomes plenos são caracterizadores típicos, descrevem pessoas, objetos, animais, atividades e eventos, ao passo que shell nouns, embora mostrem, pela frequência de uso, uma relação estável com tipos de experiências, como, por exemplo, problema (atitudinal), ideia (estado mental), resposta (ato de fala), fato (status epistêmico), caso (contingência), em razão da semântica abstrata e inespecífica, sempre irão depender de informações contextuais para completar sua interpretação. Relacionada à função semântica está a função cognitiva, que se refere ao potencial dos shell nouns para constituir formações conceituais temporárias. Apesar de os shell exibirem uma afinidade com tipos de experiência, os conceitos encapsulados por eles são variáveis, daí a natureza temporária, em que o conteúdo muda a cada contexto. Por sua vez, a função textual se refere ao potencial anafórico encapsulador dos shell nouns, que restringe as possibilidades de interpretação ao entorno contextual.

Assim, a singularidade dos nomes que funcionam como shell é conferida pela correlação estreita entre as três funçôes e por um balanço entre estabilidade conceitual e flexibilidade de informaçáo, de modo que "It is this combination of stability and flexibility that turns shell nouns into such powerful communicative and cognitive tools" (Schmid 2000: 19). Nessa perspectiva, assumo que caso atua como um shell noun que comporta informação circunstancial sobre eventos, particularmente envolvendo a noção de contingência, em que caso é concebido como algo que acontece, aconteceu ou poderá acontecer a qualquer instante.

Nos dados investigados, o padrão nominal de caso exibe pelo menos três contextos estruturais: caso é núcleo de sintagma nominal ou está dentro de sintagma preposicional e, no segundo caso, pode atuar ou não como correlato enfático de uma oraçáo condicional. A Tabela 3, a seguir, mostra as frequências dos padróes nominais, em perspectiva longitudinal, relacionando as categorias aos respectivos valores. Os percentuais de caso em sintagma preposicional são maiores em praticamente todas as sincronias. 


\begin{tabular}{lllcccccc}
\hline \multicolumn{1}{c}{ VAlOR } & CATEGORIA & XIV & XV & XVI & XVII & XVIII & XIX & XX \\
\hline circunstância & nome & $5 / 18$ & $21 / 101$ & $39 / 130$ & $100 / 182$ & $16 / 89$ & $56 / 137$ & $52 / 157$ \\
específica & & $28 \%$ & $21 \%$ & $30 \%$ & $55 \%$ & $18 \%$ & $41 \%$ & $33 \%$ \\
circunstância & nome & $9 / 18$ & $70 / 101$ & $64 / 130$ & $68 / 182$ & $42 / 89$ & $63 / 137$ & $61 / 157$ \\
específica & em Sprep & $50 \%$ & $69 \%$ & $50 \%$ & $37 \%$ & $47 \%$ & $46 \%$ & $39 \%$ \\
correlato enfático & nome & $3 / 18$ & $8 / 101$ & $8 / 130$ & - & $3 / 89$ & - & - \\
condicional & em Sprep & $16 \%$ & $8 \%$ & $6 \%$ & & $3 \%$ & & \\
\hline
\end{tabular}

Tabela 3. Frequência dos contextos nominais de caso em perspectiva longitudinal

A inespecificidade inerente à semântica de caso é moldada, nos diferentes contextos de uso, a partir da saturaçáo de sua lacuna argumental, com a consequente formação conceitual temporária de uma circunstância especifica, que, nas ocorrências de (13) a (15), é expressa em eventos associados ao mundo sócio-físico, a saber, a situação de uma perna quebra, a existência de autoria, ou o impedimento de cavalgar.

(13) E foi preso de El-Rei Dom Fernando, por caso da perna quebrada. (14CDA)

(14) Assi se guarda nos casos en que ha outor. (14DCS)

(15) Meu caso de não poder cavalgar. (14CDA)

Quando inserido em sintagma preposicional, sobretudo na presença de demonstrativo, como em neste caso, em tal caso, o sintagma recupera e encapsula, por anáfora, um conteúdo proposicional veiculado anteriormente, como ocorre em (16), um excerto de texto prescritivo extraído da amostra do século xx:

(16) Deixe-se cozer por três horas, em fogo brando, e veja-se se a espadua está cozida; n'esse caso, tire-se do fogo, extráia-se-lhe todo o liquido espremendo-a, e deixe-se arrefecer antes de tirar o panno que a envolve. (20CDC)

Em (16), nesse caso retoma o conteúdo proposicional prévio a espádua estar co$z i d a$, reinterpretando-o e articulando-o ao conteúdo da oraçáo subsequente tire-a do fogo e extraia todo o liquido espremendo-a, em uma construção complexa intercambiável com uma hipotática condicional (se estiver cozida, tire do fogo e extraia o líquido). A presença do demonstrativo é decisiva para o movimento de retomada, tanto que na sua ausência, as expressóes no caso ou em caso carecem da habilidade de recuperar um conteúdo proposicional e por isso deixam aberta uma lacuna proposicional saturável, que pode dar lugar a processos de adjunção por meio da preposição de ou da conjunção que, resultando em construçóes do tipo: no caso de a espádua estar cozidal no caso em que esteja cozida. Em outras palavras, a semântica genérica e inespecífica de caso como shell noun exige alguma forma de complementaçáo, o que pode se resolver com a participação do demonstrativo anafórico, em que nome e pronome contíguos 
são reanalisados como expressóes adverbiais juntivas, neste casol em tal caso. Em outros contextos, a complementação se resolve com a participação de conjunção ou de preposição (Seçôes 5.2 e 5.3, respectivamente).

As expressóes adverbiais juntivas que veiculam nuança condicional, à maneira de (16), são frequentes em todos os estados de língua e parecem estar na origem da derivação histórica, o que corrobora a hipótese de Barra Jover (2002), referida anteriormente ${ }^{10}$. Seguem em (17) a (21) exemplares do português arcaico, extraídos de textos prescritivos ${ }^{11}$. Em (17), há reiteraçấo do demonstrativo na expressão em tal caso como este. Nos demais, em tal(is) caso(s) funciona como correlato enfático de uma condicional introduzida por gerúndio, em (18), e por se, em (19)-(21). No papel de correlato enfático, em tal caso assume o valor de prótase condicional, instaurando uma manobra argumentativa de retomada e de avanço, em que recupera anaforicamente o conteúdo prévio, encapsulando-o e colocando-o em relação com o conteúdo subsequente.

(17) Ora seia cố razô ora sẽ razố e mãdã aos seus criados que lhes uaã fazer mal ou os matar é tal caso como este mais peca o que o manda ca o que o faz. (15TC)

(18) E querendo esse Official citar alguum privilegiado fora da dita Comarqua, assy como Viúva, Orfâaoo, ou pessoa miseravel; em taees casos Mandamos que lhe nom seja dada Carta. (15LMP)

(19) [...] E se o fogo per cajom fezer algum mal, em tal caso ponha-se a petiçom no rool, posto que nom traga estromento de contentamento. (15LMP)

(20) E se for contenda antre Judeo, e Judeo, em tal caso poderá cada hum delles dar por testemunha Chrisptáao contra Judeo, e vallerá seu testemunho, assy como se fosse antre Chrisptáao, e Chrisptãao. (15LMP)

(21) Enxẽplo: Eras sacristã e tágias o syno e cayo o badalo e matou huũ home, tu por yso boa obra fazias, ẽpero se tu nó uisitauas o badalo se estaua bem legado ou se era podre o legamẽto ou quando tu uias que caya o badalo e nó braadauas a gente que pasaua que se gardase, $\tilde{e}$ tal caso porque ẽ teu oficio nô poseste boa diligencia e per tua negligẽcia acôteceu aquel caiô. (15TC)

10. Também Brinton (2007) reúne evidências diacrônicas de que any time, each time e every time, que atuam como subordinadores adverbiais no inglês contemporâneo, sobretudo em textos de gêneros informais, resultam de dois estágios de mudança. No primeiro, sintagmas preposicionais com núcleo nominal são reinterpretados como advérbios, em um processo que envolve conjuntamente o abandono da preposição e a perda de propriedades nominais e, no segundo, advérbios são reinterpretados como conjunçóes subordinativas que exprimem contingência temporal, em um processo que envolve crescentemente fixação sintática e mudança semântica.

11. Os textos reunidos nas siglas 15LMP e 15TC, de onde extraí os dados de (17) a (21), se referem, respectivamente, à esfera do direito e da religião. 15LMP trata de um conjunto de leis medievais portuguesas, e 15TC, de instruçóes do clero sobre o modo de administrar o sacramento da penitência. São textos essencialmente prescritivos, que favoreceram a identificação de condicionais, especialmente daquelas com caso. 
As evidências e interpretaçóes reunidas nesta seção indicam fortemente que o contexto em que caso integra sintagma preposicional com demonstrativo é um estágio crucial para a mudança. O sintagma em tal caso (menos frequentemente, neste caso) dá conta da saturação de caso e, ao mesmo tempo, assume um significado contextual temporário que dispara uma relação com o conteúdo da oração posterior, em termos de uma intervenção causal possivel, que é a essência da condicionalidade (Sweetser 1990). O conteúdo encapsulado por em tal caso passa a ser entendido como suficiente para habilitar a verdade da oração nuclear e, assim, o sintagma funciona como indicador da relação de implicação entre os dois conteúdos. Aliado à manobra interpretativa está um correlato formal importante, que é a posição frontal ocupada pelo sintagma, antecipando-se ao conteúdo que se apresentará como resultado ou consequência. Esse fronteamento está em conformidade com o padrão de ordenação típico de condicionais: se $p$, $q$. Em outras palavras, os sintagmas encapsuladores parecem compor o contexto motivador do estágio inicial de reanálise sintático-semântica de caso, que de shell noun com valência $1\left(\right.$ Caso $\left._{\mathrm{x}}\right)$ passa a conjunçáo, com valência $2\left(\right.$ Caso $\left._{\mathrm{X}, \mathrm{Y}}\right)$. Além disso, é nos sintagmas preposicionais que se opera uma alteração semântica fundamental que traz consequências para a gramaticalização de caso: ao recuperar anaforicamente um conteúdo proposicional, em contexto específico, esse conteúdo é que passa a ser relevante para a interpretação, não mais os traços semânticos genérico e inespecífico da fonte.

Conclusão similar é alcançada em Granvik (2018) para construçóes com caso do espanhol. Conjugando os pressupostos teóricos da Gramaticalização e da Gramática de Construçóes, o autor investiga, em perspectiva diacrônica, o desenvolvimento que levou o nome caso, do espanhol, a funcionar como conjunçáo complexa condicional, como em: (en) (el) caso (de) que llueva, no saldremos. Concentrando-se na análise da emergência do significado condicional e das alteraçóes formais experimentadas pelas construçóes com caso, Granvik (2018) demonstra que os modelos da Gramaticalização e da Gramática de Construçôes captam aspectos diferentes e complementares dos processos de mudança em pauta. Para Granvik, na história do espanhol, tal como defendo aqui para a história do português, o contexto chave que dispara leitura condicional é aquele em que caso combina-se com en, formando a expressão adverbial en (tal) caso, cenário que predispóe a criação de inferências de condicionalidade.

\subsection{A questão da proposiçáo introduzida por que}

Diacronicamente, as construçóes perifrásticas com que mostram diferentes tipos: em caso que, sendo caso que, caso que e no(s) caso(s) (em) que. Assumindo que a interpretação das condicionais decorre não apenas do juntor, mas de todo o arranjo morfossintático e semântico de que ele participa (Dancygier 2003), é possível pressupor 
que o estatuto conjuncional dessas expressóes resulta, por um lado, de uma crescente ligação entre o nome e que, passível de avaliação em termos formais e semânticos, mas resulta também da convergência evolutiva de outros traços que são essenciais para a constituição da construção condicional como um todo, como, por exemplo, a seleçáo das formas verbais. É amplamente reconhecido na literatura que a relação de dependência entre as formas verbais indicia diferentes nuanças de condição e de atitude do falante/escrevente. $\mathrm{O}$ processo gradual de fusão de elementos para constituição das perífrases possivelmente envolveu um estágio relacionado à construção de uma correlação entre as formas verbais das oraçóes envolvidas, o que equivale a admitir que a mudança não repousa somente na constituição isolada do item conjuncional, mas em toda a construçáo que ele ajuda a formar.

Acrescente-se que o próprio estatuto de que é discutível. Kortmann (1997) afirma, em perspectiva translinguística, que é frequente o recrutamento de núcleos nominais de oraçôes relativas para a função de marcadores de subordinação adverbial. Para Visconti (2000: 87), a particularidade dos conectivos hipotéticos denominais do italiano (nel caso chelin cui, in caso, casomai) está na combinação entre a semântica do nome e um complementizador de implementação diversa. Para Barra Jover (2002: 366), com base nos dados do espanhol, há duas construções: uma com proposição anafórica e outra com relativização. Hengeveld e Mackenzie (2008: 261) também distinguem casos em que nomes temporais (time, moment, minute, hour, day, month, year) são modificados por oração relativa (p.e. The time at which he arrived was fairly late) daqueles em que são complementados por uma oração subordinada (p.e. The time that he arrived was fairly late). Camacho (2014), em estudo sobre tipologia de construçóes relativas na lusofonia, identifica um uso inovador em que a relativa passa a funcionar como argumento de nomes de tempo, lugar, modo, quantidade e razão. Para o autor, são duas as justificativas: necessidade de complementação desses nomes (p.e. hora de trabalho; momento de descontração) e ausência de relação anafórica com o antecedente.

Conforme ilustra a Tabela 2, Seção 4, nos dados investigados, a primeira ocorrência de perífrase, que reproduzo em (22), data do século XIV. Destaco dessa construção a contiguidade entre em caso que e a conjunção se, o emprego do subjuntivo em ambas as oraçóes, e a posição inicial da perífrase na oração. $\mathrm{O}$ material das sincronias subsequentes favoreceu a observação de ocorrências que se distribuem entre complementação, conforme (23), que implica a inserção de caso em sintagma preposicional e habilita leitura de condição; e modificação, conforme (24), que não implica, nem habilita:

(22) Teemos por bem e mandamos, que estes dous homeens boons, que assy ficarem e forem escolheitos, como dito he, em caso que se as partes nom possam avyr, taixem, e alvidrem quanta, e tamanha parte, ou pensom os Lavradores dem aos Senhorios das herdades. (14OA, 408) 
(23) Em caso, que a Senhora Princeza Dona Isabel, que Deos nos guarde, falte sem successaó, que ha de fazer este Príncipe? (17CPV, 284)

(24) [...] faz muito ao entender e razom conhecer o que he melhor que se faça em os casos em que ellas per ssy se contrariom, per esta guisa. (15EBC, 118)

Além disso, o esboço diacrônico da Tabela 4 sugere que, embora em caso que seja anterior a no(s) caso(s) (em) que, ambas passam a coexistir por volta do XvI e, nos textos mais recentes, no(s) caso(s) (em) que é que prevalece mais frequentemente. Mais uma vez, os resultados obtidos reforçam aqueles de Gerards e Kabatek (2018). Para os autores, a trajetória em caso que > no caso que, embora pareça contrariar expectativas acerca da redução formal que acompanha a mudança, ela é compreensível tendo em vista que, na gramaticalização do artigo, sintagmas preposicionais são os contextos em que o artigo é atestado mais tardiamente.

Há algumas poucas ocorrências que evidenciam ainda a gradiência na constituição da perífrase, conforme (25) a (27). Nelas, há preservação do artigo e presença de algum tipo de material interveniente entre caso e que, às vezes, a presença de um modificador adjetivo (conforme grifos). Esses traços, contemplados em Kortmann (1997) e em Heine e Kuteva (2007), reforçam a relativa analisabilidade da construção.

(25) [...] se mandarão os papeis authenticos ao dito Senhor; e no caso (o que Deos naô permita) que esta gente se torne a meter nos matos, e fazernos guerra, os damnos, que de antes se temiaó, e quam perdidas ficaráó as esperanças de se reconciliarem já mais por nenhuma via. (17CPV, 111)

(26) E quem vendeo hum Príncipe por inteligências, e conveniências com Castella, porque naô venderá hum Reyno pelas mesmas dependências, e conveniências, que Castella lhe fará mayores, principalmente no caso supposto, em que naô haja successaô. (17CPV, 286)

(27) Até no cazo negado, que o tio e Sobrinho se ajustassem sobre esta materia, nem por isso seriaó nullas todas as Sesmarias precedentes. (18CSA, 103)

As perífrases existenciais com sendo caso que também são opções para expressão de condição já nos textos do século XIV, como em (8) anterior. Trata-se de construçôes complexas condicionais em que a cópula existencial (nesse caso ser, muito raramente haver) traz à cena a asserção de uma circunstância possível, contextualmente saliente, ao mesmo tempo em que a proposiçáo iniciada por que satura o nome caso. Como mostram os dados de (28) a (30), a construção tem características sintático-semânticas bastante regulares: as orações encabeçadas por sendo caso que veiculam sempre informaçáo disponível ou acessível no contexto linguístico, favorecendo sua anteposição, são construídas necessariamente com modo subjuntivo e se conformam a condicionais preditivas e hipotéticas. 
(28) [...] porque se devia preferir o valor e ânimo de tal capitão a qualquer defeito natural ou acidental corporal, mostrando o jeito do olho; mas sendo caso que náo possa ser, encubra-se o defeito da tal pessoa. (16PP, 27)

(29) [...] e ultimamente lhe dá sua palavra de que não fará nunca pazes com o imperador, e que sendo caso que as faça será a primeira condição. (16GZ, 4)

(30) Sendo caso que ainda falleçaó alguns Marinheiros, ou Grumetes obrigados a esta náo, e tiverdes necessidade delles para a navegação, pedillos-ha o Capitão, e Mestre ao Governador (18SCR, 17)

\subsection{O estatuto das perífrases preposicionais}

Nas línguas, os nomes estão entre as fontes mais importantes para a constituição de preposiçôes complexas (Kortmann \& König 1992: 671). As construçôes preposicionais com caso são examinadas à luz de parâmetros que permitem aferir graus maiores ou menores de analisabilidade e de composicionalidade. Com base em Kortmann (1997) e em Bybee (2010), investigo o grau de fusão entre as partes do composto, a perda de propriedades das formas fonte e a relação de significado dependente ou não da recuperabilidade das partes.

Para mensurar o grau de fusão, elejo quatro aspectos que permitirão refletir sobre a analisabilidade do sintagma e, portanto, sobre o estatuto de preposição complexa: i) inserção de material interveniente em algum ponto do sintagma (31), em que, quanto maior o grau de fusão, menor a frequência de material; ii) elipse de parte do sintagma em contextos de coordenação (32), em que, quanto maior o grau de fusão, menores as chances de elipse; iii) coordenação entre o sintagma preposicional e uma palavra gramatical de valor similar (33), que reforça o estatuto preposicional do sintagma; e, iv) encadeamento múltiplo (34), com um sequenciamento de ocorrências, que evidencia a propriedade fixa do composto.

(31) (...) no caso, porém, de ser este graduado no posto immediatamente superior considerar-se-á como si estivesse effectivamente provido na classe de que tiver a graduação. (20BM, 66)

(32) Tudo isto se entende no cazo de naó haver traiçaó, e de se cometer este Crime só por negligencia. (18CMD, 79)

(33) O mesmo ocorre se houver conflito entre os referidos representantes, se não há titular de direito conhecido ou em caso de vaga ou de deserdação. (20RFD, 64)

(34) A Constituição de 1969, até a promulgação da Emenda n. ${ }^{\circ} 11 / 78$, facultava ao Presidente da República a decretação do estado de sítio nos casos de "grave perturbação da ordem ou ameaça de sua irrupçáo" ou ainda no caso de guerra. (20RFD, 151) 
Os dados (31) e (32) apontam para graus mais elevados de analisabilidade do sintagma, enquanto os de (33) e (34) apontam para a perda de analisabilidade. Em perspectiva longitudinal, conforme a Tabela 4 , as evidências mais significativas, em termos de frequência, se relacionam à elipse de parte do sintagma, inclusive em dados recentes da língua, reforçando a legitimidade das partes e sinalizando que a fusão (e, portanto, a gramaticalização) ainda é relativa. Nesses termos, apesar de lidar com um número baixo de ocorrências de perífrase, conforme ressalva feita anteriormente, a análise qualitativa dos dados forneceu evidências suficientes para responder à questáo de pesquisa cerca do grau de gramaticalização da construção (cf. Seção 4).

\begin{tabular}{lcccc}
\hline \multicolumn{1}{c}{ ParÂMETros } & XVII & XVIII & XIX & Xx \\
\hline Presença de material interveniente & - & - & - & $1 / 32$ \\
Elipse de parte do sintagma & - & $3 / 12$ & - & $12 / 32$ \\
Coordenação com conjunção simples & - & - & - & $1 / 32$ \\
Encadeamento múltiplo & - & - & - & $1 / 32$ \\
\hline
\end{tabular}

Tabela 4. Frequência de aplicação do parâmetro grau de fusão dos elementos do sintagma

Quanto ao segundo parâmetro, perda de propriedades das formas fonte, focalizo aspectos morfossintáticos que essencialmente caracterizam o nome caso, tais como a tomada de determinantes e de modificadores e a flexão em número. Os resultados, em perspectiva longitudinal, na Tabela 5, mostram que um aspecto saliente é a preservação do determinante artigo, como exemplificam (35) e (36):

(35) [...] Que senão rasguem as folhas, e no caso de alguém as ver rasgar, ir logo denunciar á junta; ou conselho da Saúde. (18HPL, 16)

(36) "Caberá ação regressiva contra o funcionário responsável, nos casos de dolo ou culpa $[\ldots]$ ". (20RFD, 99)

\begin{tabular}{lcccc}
\hline \multicolumn{1}{c}{ PARÂMETros } & XVII & XVIII & XIX & XX \\
\hline habilidade de receber determinantes & $2 / 5$ & $10 / 12$ & $4 / 5$ & $18 / 32$ \\
habilidade de receber modificadores & $0 / 5$ & $0 / 12$ & $0 / 5$ & $0 / 32$ \\
flexão em número & $0 / 5$ & $1 / 12$ & $0 / 5$ & $4 / 32$ \\
\hline
\end{tabular}

Tabela 5. Frequência de aplicação do parâmetro perda de propriedades da fonte nominal

A expectativa era a de perda crescente do artigo definido, mas continuam em uso, no português contemporâneo, ambas as construçôes em caso de e no(s) caso(s) de. Além da analisabilidade mais acentuada de no(s) caso(s) de, há também dados em 
que a composicionalidade, terceiro parâmetro aplicado, é mais evidente, pois sequer admitem leitura condicional, diferentemente de em caso de, que sempre estabelece relação de condição. A esse respeito, compare (37) e (38), extraídos do Código Civil Brasileiro (CCB):

(37) O Conselho será presidido pelo Ministro do Supremo Tribunal Federal, que votará em caso de empate, ficando excluído da distribuição de processos naquele tribunal. (CCB)

(38) No caso do parágrafo antecedente, o juiz fixará a justa indenização devida ao proprietário; pago o preço, valerá a sentença como título para o registro do imóvel em nome dos possuidores. (CCB)

A ocorrência em (37), mas não em (38), tem leitura condicional e pode ser parafraseada por se houver. Em pesquisa em andamento, fundada em obras jurídicas do português brasileiro contemporâneo, verifiquei centenas de ocorrências similares a (37) e (38). As frequências têm mostrado que uma diferença essencial entre elas, além dos aspectos discutidos anteriormente, está na forma do complemento: em caso de é complementado por nomes nus na quase totalidade das ocorrências, ao passo que a construção com no(s) caso(s) de, além de nomes nus, aceita nomes determinados, como em (38). Nomes nus, conforme (37), têm interpretaçáo generalizante e carregam indicaçáo de pluralidade e, portanto, parecem mais aptos à criaçáo de cenários hipotéticos do que nome determinados, que assumem uma referência definida, conforme o parágrafo antecedente, em (38). Além disso, parágrafo não é propriamente o tipo de entidade que pode saturar a lacuna argumental de caso e especificar uma circunstância contingente, o que explica a dificuldade em se construir uma leitura condicional para essa ocorrência.

\subsection{A relação condicional nas construçóes com caso}

Nesta seção, examino o tipo de relação condicional expresso nas construções complexas, cotejando particularmente os usos das perífrases conjuncionais em(o) caso (em) que e sendo caso que e aqueles envolvendo a conjunção simples caso, com a expectativa de apreender algum índice que permita contemplar a hipótese de derivaçáo histórica entre essas construções, conforme argumentei na Seção $4^{12}$. A frequência de emprego da conjunçáa caso é baixa nos dados desta pesquisa (rever Tabela 2), o que significa que as generalizaçóes feitas aqui não são de modo algum categóricas. Os

12. Os fatos em torno da constituição da conjunção condicional simples caso representam um estágio evolutivo singular da história do português, não evidenciado na história do espanhol, conforme Granvik (2018). 
dados mostram que as construções que envolvem a conjunção caso são condicionais hipotéticas, fundadas na consideração de circunstâncias possíveis, recuperáveis direta ou indiretamente no contexto prévio. Requerem subjuntivo na prótase e a ordem das orações no complexo é variável, possivelmente correlacionada a funçôes discursivas específicas. Nos contextos de anteposiçáo da prótase, conforme (39), a condicional com caso mobiliza um cenário hipotético dentro do qual o conteúdo da oração núcleo pode ser considerado legítimo, ao passo que, nos contextos de posposição, conforme (40), a condicional pode sinalizar uma ressalva, justificativa, retificação a posteriori ou alguma forma de especificaçáo das circunstâncias sob as quais o conteúdo da núcleo se mantém:

(39) Não exijo pagamento a parte das minhas bemfeitorias, porque tendo eu já tirado alguma madeira, é justo que de algum modo recompense este prejuizo. A escriptura deverá passada por todo mez de agosto, e caso náo o faça o pretendente a compra perderei o direito a garantia que ficará em meu poder. (19CWL, 72)

(40) [...] O mesmo senhor avisou me que o doutor Dolzani era possuidor de uma ordem de retenção dada pelo excelentísssimo doutor juiz de direito, e nessa mesma occasião dava-se o encontro da pedra com os meus empregados a quem tinha acompanhado para tirarmos dos carregadores a pedra, caso não fosse acompanhado de autoridade. (19CCB, 76)

As circunstâncias possíveis colocadas em cena na estrutura condicional são pautadas em experiências reais, contingentes, no domínio sócio-físico (Sweetser 1990), o que sugere que as condicionais articuladas com a conjunção caso são tipicamente (ainda que não exclusivamente) condicionais de conteúdo, reforçando, assim, teses filogenéticas referidas anteriormente.

As perífrases conjuncionais com caso, cronologicamente anteriores, mostram afinidades com (39) e (40), fortalecendo a hipótese de derivação. Essas afinidades repousam sobretudo na base circunstancial contingente, na condicionalidade hipotética no domínio sócio-físico, na maleabilidade da ordem e consequentes efeitos discursivos. Confira as semelhanças entre os usos antepostos de (41)-(42) e (39), e os usos pospostos de (43)-(44) e (40):

(41) Pelas quais razôes todas, eu hei por meu serviço que vós não façais o concerto que tínheis praticado em nenhuma maneira. E em caso que tenhais concertado, hei por bem que vós desconcertes em todas as maneiras. $(16 \mathrm{C}, 38)$

(42) [...] Ordeno que os Thesoureiros tenhaó quadernos de despeza de cada dia, feita desde a segunda feira de cada semana até o sabbado. [...] No caso que ao sabbado se naó possaó ajustar todas as contas dos Thesoureiros, se ajustaráó na segunda feira da semana seguinte. (18SCR, 49) 
(43) Por tanto eu Egas Moniz faço doação a vós minha mulher, Dona Tareja Afonso, da metade de minha fazenda, e da terra, que deixar por minha alma, para que a possuais enquanto viverdes, em caso que eu morra primeiro. (16ML, 79)

(44) [...] mandou levantar um forte de mandeira, prevenindo, como capitáo e prudente, hù lugar seguro, onde se defendesse no cazo que os índios lhe fizessem alguma oposição. (18CSA, 9)

As construçóes existenciais com caso, fortemente hipotéticas, parecem divergir das anteriores apenas no que toca à posiçáo. Como discuti anteriormente, as prótases com sendo caso que, de que (45) e (46) são exemplares, mostraram-se categoricamente antepostas. Sáo ocorrências que se aproximam de condicionais de atos de fala.

(45) [...] lhe vim enfim a dizer, que sendo caso que o matassem, como ele dizia, a fim de lhe roubarem aquela fazenda, que onde poderia eu escapar que me não fizessem o mesmo? (16P, 55)

(46) E sendo caso que chegando as náos a este Reino se ache alguma fazenda, que venha fora do registo, que ordena a Proviasô referida, e este Alvará, mando que seja perdida irremissivelmente na fôrma da dita Lei. (18SCR, 42)

\section{Conclusões}

A investigação sobre os processos diacrônicos de mudança inerentes à caso, na história do português (PE e $\mathrm{PB})$, trouxe resultados importantes para explicaçáo dos contextos que contribuíram para as mudanças de caso rumo à junçáo condicional, para reforço de relaçóes de derivação entre as construçóes com caso e para a apreensão da gradualidade na constituição das categorias novas.

A descrição das propriedades da fonte nominal caso, em termos de seu funcionamento como shell noun, contribuiu para a compreensáo da predisposição de caso às diferentes trajetórias de mudança. A semântica abstrata e inespecífica de caso, de base circunstancial contingente, aliada à função textual encapsuladora, restringe a interpretação de caso ao entorno contextual, exigindo alguma forma de complementação. Nessa perspectiva, o contexto específico em que o nome caso integrava sintagmas com demonstrativos (tal caso, neste caso), reinterpretado como uma expressão adverbial juntiva, parece representar o ponto de partida para a conjunção condicional. Os dados evidenciaram, já no português arcaico, que o sintagma nucleado por caso retomava uma construção condicional precedente, assimilando seu significado ou ainda atuando como correlato enfático condicional. Na ausência do demonstrativo, a complementaçáo se resolvia por meio de que ou com $d e$, o que favoreceu a constituição de 
perífrases. Dos correlatos formais que participaram da mudança, destaco o peso do modo subjuntivo na prótase, acrescendo uma projeção futura, e o enrijecimento da ordem com a anteposição do sintagma, conformando-se, assim, à ordenação típica de prótases condicionais.

A análise do tipo de relação condicional expresso nas construçóes com caso, especialmente em termos de domínios pragmáticos, foi tomada como lugar para avaliar teses filogenéticas e para aferir uma possível relação de derivação entre a conjunção simples caso e as formas perifrásticas. Os resultados apontaram para uma prevalência de condicionais hipotéticos de conteúdo em ambas as formas simples e complexas, o que fortalece a tese de que o domínio sócio-físico é anterior aos domínios mental e conversacional, e soma mais evidências à hipótese de derivação.

O refinamento e a aplicação de critérios para mensurar a composicionalidade e a analisabilidade das construçóes perifrásticas com caso permitiram expor aspectos de gradiência, tão característicos da constituição das novas construçóes e, ao mesmo tempo, evidenciar que, no português contemporâneo, convivem construçóes que atravessam estágios diferentes de mudança. As perífrases conjuncionais mostraram instabilidade formal, com arranjos que ainda preservam o artigo e/ou o modificador, resquícios da sintaxe da forma fonte, além de construçóes que admitem a inserção de material diverso entre caso e que. No caso das perífrases preposicionais, os dados indicaram que a diferença entre em caso de e no caso de não repousa somente no aspecto formal, de analisabilidade, em que a segunda preserva o artigo, mas repousa também no significado: em caso de, em todas as ocorrências analisadas, habilita leitura condicional, ao passo que no caso de só habilita em certas estruturas, mostrando índice mais alto de composicionalidade.

Voltando aos postulados de Traugott (1985), sobre as fontes mais frequentes para marcadores de prótases condicionais, a história de caso, tal como descrita aqui, sugere uma surpreendente convergência entre quatro delas: modalidade epistêmica, temporalidade, cópulas existenciais e topicalidade. O significado genérico de caso, relacionado à contingência temporal, reveste-se de um teor epistêmico (fato, evento, ocorrência, eventualidade, conjuntura, situação, hipótese, possibilidade, condição exemplificativa), condizente com a expressão de condição, como atesta a literatura (Kortmann 1997; Brinton 2007; Schmid 2000, 2007). A foricidade e a topicalidade de caso, em seu funcionamento como nome shell, são bastante acentuadas. As construções existenciais com sendo caso que, que estão entre as primeiras formaçóes conjuncionais com caso, já expressavam possibilidades contextualmente salientes. Esses fatos corroboram a reconhecida afinidade informacional entre marcadores de tópico e marcadores de prótase condicional. Em diversas línguas (Traugott 1985; Mithun 1988), um canal fértil de criação de conjunções está justamente na derivação a partir de advérbios fóricos, que veiculam informação partilhada.

Guardadas as especificidades, a história de caso recupera em grande parte a história de $s \grave{\imath}$ latino. Na origem de ambos está a foricidade e a reinterpretação de uma 
porção de informação pressuposta em termos de condição pressuposta. Segundo Ernout e Meillet (1951: 1098), sī é forma derivada do antigo advérbio pronominal sīc que, com valor de neste caso ou assim, atuava como marcador de tópico, ocupando posição inicial na oração. A esse respeito, Gerards e Kabatek (2018) argumentam que o partilhamento da mesma relação conceitual nas trajetórias análogas de si latino e de caso indicia que o português desenvolveu uma nova conjunção condicional por meio da reutilização de uma trajetória já atestada em sua história.

\section{Agradecimentos}

Agradeço ao CNPq - Conselho Nacional de Desenvolvimento Científico e Tecnológico pelo apoio financeiro, no âmbito dos processos 304854/2014-0 e 305901/20176. Agradeço especialmente aos revisores anônimos pela análise crítica e sugestóes que muito contribuíram para o refinamento deste trabalho. Possíveis equívocos e/ou inconsistências que persistirem são de minha total responsabilidade. 


\section{Referências bibliográficas}

Alexe, Raluca. 2013. Classification of complex conditional connectives in Romanian. Bulletin of the Transilvania University of Brasov vol. 6, 55, n. 2, 35-40. Séries IV: Philology and Cultural Studies.

Ali, Manuel Said. 1931. Grammatica histórica da língua portuguesa. São Paulo: Melhoramentos.

Barra Jover, Mario. 2002. Propiedades léxicas y evolución sintáctica. El desarrollo de los mecanismos de subordinación en español. Noia (A Coruña): Toxosoutos.

Barreto, Terezinha Melo. 1999. Gramaticalização das conjunçōes na história do português. Universidade Federal da Bahia. (Tese de doutoramento).

Blühdorn, Hardarik. 2008. Subordination and coordination in syntax, semantics and discourse: evidence from the study of connectives. Em Cathrine Fabricius-Hansen \& Wiebke Ramm (eds.), Subordination versus Coordination in Sentence and Text. 59-85. Amsterdam: Benjamins. https:// doi.org/10.1075/slcs.98.04blu

Brinton, Lauren. 2007. Rise of the adverbial conjunctions (any, each, every) time. Em Ursula Lenker \& Anneli Meurman-Solin (eds.), Connectives in the history of English. 77-96. Amsterdam: John Benjamins. https://doi.org/10.1075/cilt.283.06bri

Bybee, Joan. 2010. Language, usage and cognition. Cambridge: Cambridge University Press. https:// doi.org/10.1017/CBO9780511750526

Bybee, Joan. 2015. Language change. Cambridge: Cambridge University Press. https://doi. org/10.1017/CBO9781139096768

Camacho, Roberto Gomes. 2014. Construçóes relativas nas variedades do português: uma interpretação discursivo-funcional. Filologia e Linguistica Portuguesa, 15, 179-214. https://doi.org/10.11606/ issn.2176-9419.v15i1p179-214

Câmara, Joaquim Mattoso. 1979. História e estrutura da língua portuguesa. Rio de Janeiro: Padrão Editora.

Dancygier, Barbara. 2003. Conditionals and prediction: time, knowledge, and causation in conditional constructions. Cambridge: Cambridge University Press. https://doi.org/10.1017/CBO9780511486463.008

Ernout, Alfred \& Antoine Meillet. 1951. Dictionnaire etymologique de la langue latine: histoires des mots. Paris: Librairie Klincksieck.

Gerards, David Paul \& Johannes Kabatek. 2018. Grammaticalization, distance, immediacy and discourse traditions: the case of portuguese caso. Em Salvador Pons Bordería \& Óscar Loureda Lamas (eds.), Beyond Grammaticalization and Discourse Markers. 115-159. Leiden/Boston: Brill. https://doi.org/10.1163/9789004375420_006

Granvik, Anton. 2015. Oraciones completivas de sustantivo: un análisis contrastivo entre portugués y español. Verba 42, 347-401. https://doi.org/10.15304/verba.42.1856

Granvik, Anton. 2018. The development of the conditional caso construction in Spanish. Em Evie Coussé / Peter Andersson \& Joel Olofsson (eds.), Grammaticalization meets construction grammar. 205-239. Amsterdam / Philadelphia: John Benjamins. https://doi.org/10.1075/cal.21.c8

Heine, Bernd \& Tania Kuteva. 2007. The genesis of grammar: a reconstruction. New York: Oxford University Press.

Hengeveld, Kees \& John Lachlan Mackenzie. 2008. Functional discourse grammar: a typologically based theory of language structure. Oxford: Oxford University Press. http://dx.doi.org/10.14198/ ELUA2009.23.18 
Herman, József. 1963. La formation du système roman des conjonctions de subordination. Berlin: Akademie-Verlag.

Kortmann, Bernd \& Ekkehard König. 1992. Categorial reanalysis: the case of deverbal prepositions. Linguistics 30, 671-697. https://doi.org/10.1515/ling.1992.30.4.671

Kortmann, Bernd. 1997. Adverbial subordination: a typology and history of adverbial subordinators based on European languages. Berlin / New York: Mouton de Gruyter. https://doi. org/10.1515/9783110812428

Leão, Ângela Vaz. 1961. O periodo hipotético iniciado por 'sé. Belo Horizonte: Editora da Universidade Federal de Minas Gerais.

Maurer, Theodoro Henrique. 1959. Gramática do latim vulgar. Rio de Janeiro: Acadêmica Editora.

Meillet, Antoine. 1912. Linguistique historique et linguistique générale. Paris: Libraire Honoré Champion. https://doi.org/10.1017/s0009840x00015493

Mithun, Marianne. 1988. The grammaticization of coordination. Em John Haiman \& Sandra Thompson (eds.), Clause combining in grammar and discourse. 331-359. Amsterdam / Philadelphia: John Benjamins Publishing Company. https://doi.org/10.1017/s0022226700014778

Montolío, Estrella. 2000. On affirmative and negative complex conditional connectives. Em Elizabeth Couper-Kuhlen / Bernd Kortmann (eds.), Cause, condition, concession, contrast: cognitive and discourse perspectives. 143-171. Berlin: Mouton de Gruyter.

Raible, Wolfgang. 2001. Linking Clauses. Em Martin Haspelmath / Ekkehard Konig / Wulf Öesterreicher \& Wolfgang Raible (eds.), Language Typology and Language Universals - an International Handbook. 590-617. Berlin / New York: De Gruyter.

Schmid, Hans-Jörg. 2000. English Abstract Nouns as Conceptual Shells: From Corpus to Cognition. Berlin / New York: Mouton de Gruyter. https://doi.org/10.1515/9783110808704

Schmid, Hans-Jörg. 2007. "Non-compositionality and Emergent Meaning of Lexico-grammatical Chunks": a corpus study of noun phrases with sentencial complements as constructions. Zeitschrift für Anglistik und Amerikamistik 55.3, 313-340. https://doi.org/10.1515/zaa.2007.55.3.313

Sweetser, Eve. 1990. From etymology to pragmatics. Cambridge: Cambridge University Press.

Traugott, Elizabeth Closs. 1985. Conditional markers. Em John Haiman (ed.), Iconicity in sintax. 289-304. Amsterdam/Philadelphia: John Benjamins Publishing Company.

Traugott, Elizabeth Closs. 1995. Subjectification in grammaticalization. Em Dieter Stein \& Susan Wright (eds.), Subjectivity and subjectivisation: linguistic perspectives. 31-54. Cambridge: Cambridge University Press. https://doi.org/10.1017/cbo9780511554469.003

Trudgill, Peter. 1995. Grammaticalisation and social structure: non-standard conjunction-formation in East Anglian English. Em Robert Frank Palmer (ed.), Grammar and meaning. 136-147. Cambridge: Cambridge University Press. https://doi.org/10.1017/cbo9780511620638.008

Visconti, Jacqueline. 2000. I connettivi condizionali complessi in italiano e in inglese: uno studio contrastivo. Alessandria: Edizioni Dell'Orso. 


\section{Anexo}

Relação completa dos textos que constituem o corpus

\begin{tabular}{|c|c|}
\hline SÉCULO & Textos \\
\hline XIV & $\begin{array}{l}\text { Crônica D. Afonso (14CDA); Foros de Garvão (14FG); Livro de Montaria } \\
\text { (14LM); Primeira Partida (14PP); Crónica geral de Espanha (14CGE); Arte de } \\
\text { trovar (14AT); Dos Costumes de Santarém (14DCS); Narrativas de Linhagens } \\
(14 \mathrm{NL}) \text {; Textos Notariais (14TN); Ordenaçóes Alfonsinas (14OA). }\end{array}$ \\
\hline $\mathrm{xV}$ & $\begin{array}{l}\text { Tratado de Confissom (15TC); Teatro de Sá de Miranda (15TSM); Sacramental } \\
\text { (15S); Penintencial (15PMP); Livro das Três Virtudes (15LTV); Livro da Ensi- } \\
\text { nança e Bem Cavalgar (15EBC); Leal Conselheiro (15LC); Legislação medieval } \\
\text { portuguesa (15LMP). }\end{array}$ \\
\hline XVI & $\begin{array}{l}\text { Poesia e Pintura de Manuel de Almeida (16PP); Monarchia Lusitana (16ML); } \\
\text { Décadas (16D); Cartas de D. Joáo III (16C); Discursos vários políticos (16DP); } \\
\text { Gazeta de Galhegos (16GZ); História da Província de Santa Cruz (16HP); } \\
\text { Perigrinaçáo (16P); Colóquio dos Simples Drogas e cousas medicinais da Índia } \\
\text { (16CSD). }\end{array}$ \\
\hline XVII & $\begin{array}{l}\text { Chronica delrey D. Ioam I (17CDJ); Chronica da Companhia de Iesv (17CCI); } \\
\text { Vida do venerável padre Joseph de Anchieta (17VVP); Diólogos de varia histo- } \\
\text { ria em que se referem as vidas dos senhores Reyes de Portugal (17DVH); Cartas } \\
\text { do Padre Antonio Vieira (17CPV); Catecismo da doutrina Christaa (17CDC); } \\
\text { Voz sagrada, politica, rhetorica, e metrica do padre Antonio Vieira (17VS). }\end{array}$ \\
\hline XVIII & $\begin{array}{l}\text { Dizertação sobre as Capitanias de Santo Amaro e São Vicente (18CSA); O } \\
\text { Fazendeiro do Brazil (18OFB); Historia dos principaes lazaretos d'Europa } \\
\text { (18HPL); Systema, ou collecçáo dos regimentos reaes (18SCR); Caminhando } \\
\text { Mato Dentro (18CMD); Reflexóes sobre a vaidade dos homens (18RVH); } \\
\text { Supplemento ao Vocabulario Portuguez (18SVP); Cultura e opulência do Brasil } \\
\text { por suas Drogas e Minas (18COB). }\end{array}$ \\
\hline XIX & $\begin{array}{l}\text { Críticas, queixumes e bajulaçóes na Imprensa Brasileira (19CCB); Corres- } \\
\text { pondência passiva de Washington Luiz (19CWL); Historia e descripção da } \\
\text { febre amarella epidêmica (19HDF); O Instituto dos Meninos Cegos de Paris } \\
\text { (19IMC); Fisiologia das paixóes e afecçóes (19FPA); Systema de materia medica } \\
\text { vegetal (19SMM); Do princípio e origem dos indios do Brasil (19DPO); Notí- } \\
\text { cias para a História e Geografia (19NHG). }\end{array}$ \\
\hline$x x$ & $\begin{array}{l}\text { Brasil Marcial (20BM); O cozinheiro dos cozinheiros (20CDC); Diálogos das } \\
\text { novas grandezas do Brazil (20DNG); O Governador das Esmeraldas (20OEG); } \\
\text { História dos feitos recentemente praticados no Brasil ( } 20 \mathrm{HDF}) \text {; O café na his- } \\
\text { tória, no folclore e nas belas-artes (20CHF); Compêndio narrativo do peregrino } \\
\text { da América (20CNP); Revista da Faculdade de Direito da Universidade de São } \\
\text { Paulo (20RFD). }\end{array}$ \\
\hline
\end{tabular}

